\title{
High-Grade Breast Epithelioid Angiosarcoma Secondary to Radiotherapy Metastasizing to the Contralateral Lymph Node: Unusual Presentation and Potential Pitfall
}

Ana Luísa Cunha Isabel Amendoeira

Department of Pathology, Hospital de S. João, Porto, Portugal

\section{Keywords}

Breast-conserving surgery - Radiotherapy ·

Epithelioid angiosarcoma $\cdot$ Lymph node metastasis

\section{Summary}

Background: Breast angiosarcoma is a rare disease occurring as primary tumour or secondary to lymphoedema or radiotherapy. The more frequent use of breast-conserving therapy and radiotherapy for breast carcinoma explains the increasing diagnosis of these tumours. Case Report: We report a case of a breast epithelioid angiosarcoma which metastasized to the contralateral axillary lymph node, occurring 4 years after breast-conserving therapy with axillary lymph node dissection and radiotherapy. The patient presented skin lesions and an axillary lump (clinically diagnosed as carcinoma relapse and lymph node metastasis). Fine-needle cytology on both lesions and a core needle biopsy of the axillary lump were carried out. Differential diagnosis included carcinoma, malignant melanoma, and angiosarcoma. Immunohistochemistry confirmed the diagnosis of angiosarcoma. Conclusions: Breast angiosarcoma is a challenge - clinically, radiologically and pathologically - and requires a high index of suspicion in susceptible patients.

\section{Introduction}

Breast-conserving surgery (BCS) followed by radiotherapy (RT) is now a common option for breast cancer treatment. Postradiation vascular proliferations are a growing diagnostic problem ranging from atypical vascular lesions to angiosarcoma [1]. Breast angiosarcoma (BAS) accounts for $0.05 \%$ of all breast malignancies [2] and can be primary or secondary to

\author{
Schlüsselwörter \\ Brusterhaltende Chirurgie - Radiotherapie · \\ Epitheloides Angiosarkom · Lymphknotenmetastasen
}

\section{Zusammenfassung}

Hintergrund: Angiosarkome der Brust sind selten und treten entweder als Primärtumor oder sekundär infolge von Lymphödemen oder Radiotherapie auf. Der häufiger werdende Einsatz brusterhaltender Chirurgie und Radiotherapie beim Mammakarzinom erklärt die steigende Anzahl diagnostizierter Angiosarkome der Brust. Fallbericht: Wir berichten von einer Patientin, die 4 Jahre nach brusterhaltender Therapie mit axillärer Lymphknotendissektion und Radiotherapie ein epitheloides Angiosarkom der Brust mit Metastasierung in den kontralateralen Achsellymphknoten entwickelte. Die Patientin wurde mit Hautläsionen und einem axillären Knoten (klinisch diagnostiziert als Karzinomrezidiv und Lymphknotenmetastase) vorstellig. Es wurden Feinnadelbiopsien beider Läsionen sowie eine Stanzbiopsie des axillären Knotens durchgeführt. Differentialdiagnostisch kamen Karzinom, malignes Melanom und Angiosarkom in Betracht. Die immunhistochemische Analyse bestätigte das Vorliegen eines Angiosarkoms. Schlussfolgerungen: Angiosarkome der Brust sind eine Herausforderung - klinisch, radiologisch und pathologisch - und erfordern ein hohes Maß an Aufmerksamkeit bei der Untersuchung entsprechend gefährdeter Patienten.

radiotherapy or lymphoedema. The relative risk for developing angiosarcoma of the chest and/or breast among women with a history of invasive breast cancer has been estimated to be 11.6 [2]. The incidence of postradiation BAS has increased $[1,3]$, and data suggest that its frequency is significantly higher than previously thought [3]. We report a case of high-grade (epithelioid) angiosarcoma arising in the skin following BCS and RT, with contralateral axillary lymph node metastases.

\begin{tabular}{ll}
\hline KARGER & (1) 2011 S. Karger GmbH, Freiburg \\
1661-3791/11/0063-0227\$38.00/0 \\
$\begin{array}{l}\text { Fax +49 761 4520714 } \\
\text { Information@Karger.de } \\
\text { www.karger.com }\end{array}$ & $\begin{array}{l}\text { Accessible online at: } \\
\text { www.karger.com/brc }\end{array}$
\end{tabular}

Dr. Ana Luísa Cunha

Department of Pathology, Hospital de S. João

Al. Prof. Hernani Monteiro

4200-319 Porto, Portugal

Tel. +351 22 5512-100, Fax -338

cunha.analuisa@gmail.com 


\section{Case Report}

A 55-year-old woman presented with a 4-cm lump in the left axilla. 4 months earlier, she had been examined in our hospital for evaluation of scattered skin lesions on her right thorax and breast, near a breast surgery scar (fig. 1). 6 years earlier, she had been treated for a right breast invasive ductal carcinoma. As the tumour at presentation was $6 \mathrm{~cm}$ in width, it was decided to begin with neoadjuvant chemotherapy (CT) followed by BCS and RT. The resection specimen showed a good response to CT with tumoural regression leaving less than $10 \%$ of malignant cells and ductal carcinoma in situ with changes secondary to therapy; vascular invasion was seen. A total of 14 axillary lymph nodes were dissected, 5 with metastases and response to CT. The tumour was classified as ypT2N2MxR0 according to the American Joint Committee on Cancer (AJCC) TNM classification (6th edition). Skin lesions (clinically a carcinoma relapse) and axillary lump were both submitted to fine-needle aspiration (FNA) cytology. Smears were haematic with scattered lymphocytes and numerous isolated neoplastic large cells (high N/C ratio, round nuclei, irregular nuclear contour with reinforced nuclear membrane and fine chromatin); the nucleoli were prominent (fig. 2 A). Some binucleated cells, cell-in-cell structures, and groups of packed cells could be seen. Core needle biopsy and histological examination of the axillary lump revealed a metastatic solid proliferation with rare slit-like and papillary structures of epithelioid cells with haemorrhagic foci (figs. 2 B and C) - similar to the FNA smear cells. The mitotic index was high. Differential diagnoses were carcinoma, malignant melanoma, and angiosarcoma. Tumour cells were diffusely positive for CD31 and negative for CAM5.2, CK7, HMB45, S100 protein, oestrogen receptor, and progesterone receptor, confirming the diagnosis of angiosarcoma. The patient was treated with CT. One year after the diagnosis, abdominal skin relapse and inguinal lymph node metastasis appeared.

\section{Discussion}

$\mathrm{RT}$ is a standard procedure after BCS being reported in nearly all patients by several authors [4-6]. BAS arising in the radiated breast is a well known complication. According to recent reports, latency ranges from 2 to 9 years [7, 8]. Our patient had an 8-year latency period. The median age for secondary BAS is 65 years, and there seems to be an increased susceptibility with advancing age and a less favourable early outcome $[8,9]$. Cases of postradiation BAS are mainly high-grade [10]. Diagnosis can be a clinical and pathological challenge.

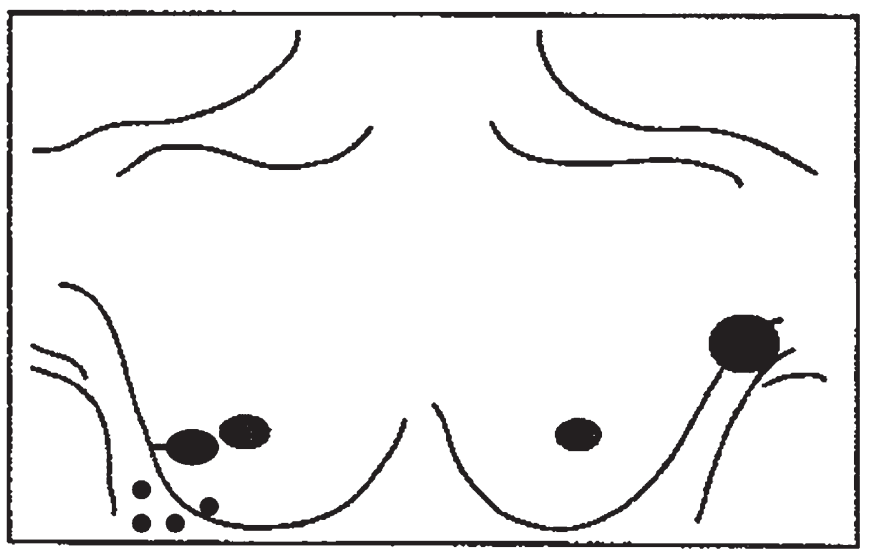

Fig. 1. Disease presentation (drawing).
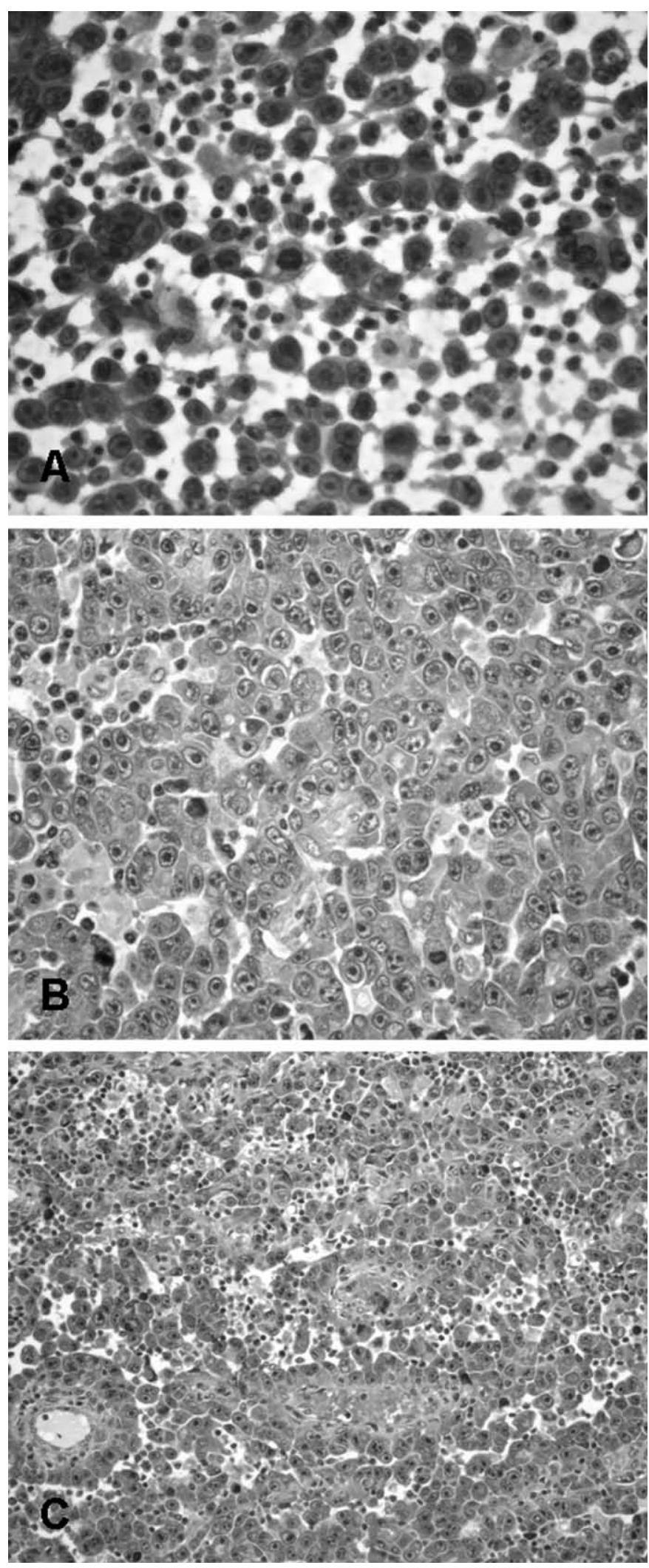

Fig. 2. A Fine-needle cytology of the axillary lump - highly cellular smear of isolated or grouped neoplastic large cells with high N/C ratio, round nuclei, irregular nuclear contour, reinforced nuclear membrane, and prominent nucleoli; B Core needle biopsy of the axillary lump solid proliferation of epithelioid cells, with $\mathbf{C}$ rare slit-like and papillary structures and haemorrhagic foci. 
Any change in colour or consistency of the skin [9] of patients treated with breast RT should alert the clinician and the pathologist to the possibility of BAS. Pitfalls of FNA can be due to either scant cellularity of spindle cells or the presence of epithelioid cells which can be misdiagnosed as carcinoma [11]. Our case raised 2 main problems: the (uncommon) epithelioid pattern and the unexpected contralateral lymph node metastases. It presented as an epithelioid malignant neoplasia, clinically diagnosed as local relapse from ductal invasive carcinoma, followed in a short interval of 4 months by lymph node metastases in the contralateral axilla. On a morphologic basis, FNA raised the differential diagnosis of carcinoma, melanoma, and less likely large cell lymphoma. Knowing that carcinoma relapse/metastasis is, in cases like this, the most important potential pitfall, the pathologist must perform immunostaining for keratins to confirm this suspicion; our case was keratin (CAM5.2, CK7)-negative. One has to be cautious because angiosarcomas, especially of the epithelioid type, can be positive for keratins and focally positive for EMA $[12,13]$. Some authors report also positivity for oestrogen and progesterone receptors [14] contributing to extra trouble if one uses only these 2 antibodies to support the diagnosis of (relapse) carcinoma. As binucleated cells and prominent nucleoli were obvious on both lesions, diagnosis of malignant melanoma was also considered but melanocytic markers (HMB45 and protein S100) performed on core needle biopsy were negative. The most useful antibodies to demonstrate endothelial cell differentiation are factor VIII, CD31, and CD34, but they can be absent in less differentiated angiosarcomas. As carcinomas do not usually stain for endothelial markers, the combined use of epithelial and endothelial antibodies is important.

BAS has a high probability of local relapse, and extra chest wall metastases are rare. Most distant metastases occur via the bloodstream (bone, lungs, liver). It can also spread to the other breast [15]. There are reports calling attention to the particular preference of epithelioid sarcomas for lymphatic vessel invasion irrespective of the primary location [16]. This particular clinicopathologic behaviour of epithelioid angiosarcoma may play a major role in delaying the diagnosis and treatment of cases like the present one.

The aim of local treatment is to achieve complete resection with clear margins to prevent local relapses and potentially prolong survival. Metastatic patients have a guarded prognosis [17]. A new treatment approach using hyperfractionated RT and accelerated RT for angiosarcoma developing after $\mathrm{BCS}$ is being used to provide a high rate of local control, disease-free survival, and overall survival [18].

In summary, the increasing use of BCS and RT for breast carcinoma will probably result in a growing number of cases of RT-induced sarcomas such as BAS. Early detection requires a high index of clinical and pathological suspicion. Whenever a patient in the right setting presents for evaluation for a carcinoma 'relapse', a panel of antibodies for vascular differentiation should be used.

\section{Acknowledgement}

The authors thank Sobrinho Simões for the support in the revision of this manuscript.

\section{Disclosure Statement}

The authors declare that they had no sources of support and that there are no conflicts of interest.

\section{References}

1 Brenn T, Fletcher CD: Postradiation vascular proliferations: an increasing problem. Histopathology 2006;48:106-114.

2 Cozen W, Bernstein L, Wang F, Press MF, Mack TM The risk of angiosarcoma following primary breast cancer. Br J Cancer 1999;81:532-536.

3 West JG, Qureshi A, West JE, Chacon M, Sutherland ML, Haghighi B, Harrison J: Risk of angiosarcoma following breast conservation: a clinical alert. Breast J 2005;11:115-123.

4 Dean CT, Jubelirer SJ, Plants BA, Welch CA: Use of radiation after breast conserving surgery (BCS) for DCIS and early invasive breast cancer at Charleston Area Medical Center (CAMC). A study of compliance with National Comprehensive Cancer Network (NCCN) guidelines. W V Med J 2009;105:34-38; quiz 39.

5 Goodwin A, Parker S, Ghersi D, Wilcken N: Postoperative radiotherapy for ductal carcinoma in situ of the breast. Cochrane Database Syst Rev 2009;(4):CD000563

6 White JR, Halberg FE, Rabinovitch R, Green S, Haffty BG, Solin LJ, Strom EA, Taylor ME, Edge SB: American College of Radiology appropriate- ness criteria on conservative surgery and radiation: stages I and II breast carcinoma. J Am Coll Radiol 2008;5:701-713.

7 Stokkel MP, Peterse HL: Angiosarcoma of the breast after lumpectomy and radiation therapy for adenocarcinoma. Cancer 1992;69:2965-2968.

8 Vorburger SA, Xing Y, Hunt KK, Lakin GE, Benjamin RS, Feig BW, Pisters PW, Ballo MT, Chen L, Trent J 3rd, Burgess M, Patel S, Pollock RE, Cormier JN: Angiosarcoma of the breast. Cancer 2005; 104:2682-2688.

9 Monroe AT, Feigenberg SJ, Mendenhall NP: Angiosarcoma after breast-conserving therapy. Cancer 2003;97:1832-1840.

10 Luini A, Gatti G, Diaz J, Botteri E, Oliveira E, Cecilio Sahium de Almeida R, Veronesi P, Intra M, Pagani G, Naninato P, Viale G: Angiosarcoma of the breast: the experience of the European Institute of Oncology and a review of the literature. Breast Cancer Res Treat 2007;105:81-85.

11 Vesoulis Z, Cunliffe C: Fine-needle aspiration biopsy of postradiation epithelioid angiosarcoma of breast. Diagn Cytopathol 2000;22:172-175.

12 Ohsawa M, Naka N, Tomita Y, Kawamori D, Kanno H, Aozasa K: Use of immunohistochemical procedures in diagnosing angiosarcoma. Evaluation of 98 cases. Cancer 1995;75:2867-2874.

13 Seo IS, Min KW: Postirradiation epithelioid angiosarcoma of the breast: a case report with immunohistochemical and electron microscopic study. Ultrastruct Pathol 2003;27:197-203.

14 Singh Y, Inoue K, Kawanishi H, Hioki K, Horio T, Shikata N, Uemura Y, T Subura A: Angiosarcoma of the breast: immunohistochemical demonstration of steroid receptors and literature review. Breast Cancer 1996;3:125-129.

15 Rosen PP, Kimmel M, Ernsberger D: Mammary angiosarcoma. The prognostic significance of tumor differentiation. Cancer 1988;62:2145-2151.

16 Dei Tos AP, Wagner AJ, Modena P, Comandone A, Leyvraz S: Epithelioid soft tissue tumors. Semin Oncol 2009;36:347-357.

17 Lahat G, Dhuka AR, Lahat S, Smith KD, Pollock RE, Hunt KK, Ravi V, Lazar AJ, Lev D: Outcome of locally recurrent and metastatic angiosarcoma. Ann Surg Oncol 2009;16:2502-2509.

18 Palta M, Morris CG, Grobmyer SR, Copeland EM 3rd, Mendenhall NP: Angiosarcoma after breast-conserving therapy: long-term outcomes with hyperfractionated radiotherapy. Cancer 2010; 116:1872-1878. 